\title{
A CONCEPTUAL MULTIDIMENSIONAL MODEL FOR ASSESSING SMART SUSTAINABLE CITIES
}

\section{Sukaina Al-Nasrawi}

Faculty of Science, Department of Mathematics and Computer Science, Beirut Arab University, Beirut, Lebanon

Carl Adams

School of Computing, University of Portsmouth, Portsmouth, United Kingdom

\section{Ali El-Zaart}

Faculty of Science, Department of Mathematics and Computer Science, Beirut Arab University, Beirut, Lebanon

\begin{abstract}
The concept of Smart Sustainable Cities (SSC) is gaining increasing attention by the countries around the globe, particularly in response to potential future environmental challenges and increased proportion of populations living in cities. Several countries claim to have implemented or in the process of implementing SSCs, and there are many models that can be used to measure how 'smart' the initiatives and cities are. This paper critically evaluates the main models to measure city smartness and identifies deficiencies, namely that they are not sensitive to the needs, resources, priorities and wider context for individual cities. The paper suggests a multidimensional methodological model that assists in evaluating the smartness level of a city while being sensitive to its context. It provides further contribution by combining sustainable and smart attributes of a city.
\end{abstract}

Keyword: Smart sustainable city; indicators; ICT; measurement; smartness.

\section{INTRODUCTION}

The urbanization boom linked to the transition from the $20^{\text {th }}$ to the $21^{\text {st }}$ century lies at the root of the emergence of the SSC concept. In the $20^{\text {th }}$ century, about $12.5 \%$ of the world population lived in cities (Townsend, 2013); however, this percentage increased to $52 \%$ in the $21^{\text {st }}$ century we are living in (UNDESA, 2012). This shows that

Manuscript first received/Recebido em: 05/07/2015 Manuscript accepted/Aprovado em: 09/11/2015

Address for correspondence / Endereço para correspondência

Sukaina Al-Nasrawi, Faculty of Science, Department of Mathematics and Computer Science, Beirut Arab University, Beirut, Lebanon E-mail: sukaina_nasrawi@ hotmail.com

Carl Adams, School of Computing, University of Portsmouth, Portsmouth, United Kingdom E-mail: carl.adams@port.ac.uk

Ali El-Zaart, Faculty of Science, Department of Mathematics and Computer Science, Beirut Arab University, Beirut, Lebanon E-mail: elzaart@bau.edu.lb 
more than half of the population of the world is living in the cities and this percentage is only expected to increase. Statistical estimations indicate that the percentage of people living in the cities will account for around $70 \%$ by 2050 . Urban inhabitants are expected to constitute $86 \%$ and $64 \%$ of the world population in developed and developing regions of the world (UNDESA, 2012).

Given this global urbanization trend and combining it with the quest of sustainable development, the concept of Sustainable Cities came to light and attracted the attention of many researchers and practitioners in the field as a desired goal for future urban development (Nam \& Pardo, 2011). Their challenge is to ensure that cities offer, for current and future generations, improved living conditions to their citizens. These conditions span over the economic, technological, social and regulatory aspects of living. According to the literature, Information and Communication Technologies (ICTs) offer high potential for solutions to many of these obstacles faced by cities while ensuring being friendly and viable to the environment (Townsend, 2013).

Currently, there exists a competition on how to interpret the concept of SSC. It has become a notion with a relatively positive connotation (Forbes, 2014). Countries around the globe aim at being associated with it as a sign of development. One group of countries claims to have developed the technical infrastructure needed for a SSC and focused on sustainable development policies. Another group of countries stresses on having improved their e-government services implementation considered to be a prerequisite for the development of a SSC (Lee et al., 2013). Other selected countries claim to have evolved towards SSCs. These claims are not evidence based as there is still no assessment model to measure the performance of SSCs. The existing models are not sensitive to the needs, resources, priorities and wider context for individual cities. Following an in depth literature review, this paper highlights deficiencies in the main models measuring smartness of SSCs and suggests a multidimensional methodological model that assists in evaluating the smartness level of a city while being sensitive to its context. It will help building an integrated vision of a city and identifying what makes cities smarter than others.

In what follows, section 2 will report on the research justification and objectives along with the questions being researched and the methodology followed. Section 3 discusses the concepts of Smart Cities (SC) and SSC and the linkages between them. Section 4 and 5 explore the definition and dimensions of SSC providing the grounds for the selection of main models listed in the literature review in section 6 . Section 7 discusses the reported models and introduces a new multidimensional methodological model aimed at assessing SSCs while sensitizing this measure with the city's context. Section 8 presents the research significance and the way forward. The paper concludes with section 9 .

\section{RESEARCH JUSTIFICATION, OBJECTIVES, QUESTIONS AND METHODOLOGY \\ 1.1. Research Justification and Objectives}

The concept of SSC, though advanced, is becoming a reality and hundreds of related initiatives around the world are taking place (IEEE, 2015). Different cities are proclaiming smartness; however as Niels Bohr says, "Nothing exists until it is measured". Therefore smartness does not exist until it is measured. To overcome selfproclamations of being a smart and sustainable city, assessment systems through 
synthetic quantitative indicators are receiving increasing attention and the need for an accurate metric of comparison that considers the city's context has become major.

Different measurement models that are relevant to the topic and adopted by the international community for their coverage to aspects of the SSC exist in the literature. However, as it will be detailed in the literature review section on the subject matter, these models do not cover all the aspects (i.e. dimensions) of a SSC. Each covers selected components of a SSC, thus the need for a multidimensional methodological model that measures the performance of a SSC from all angles while being sensitive to the city's context.

\subsection{Research Questions and Methodology}

This research highlights the needs for a multidimensional methodological model for assessing SSC while being sensitive to the context of the city under assessment. This model not only helps in assessing the performance of a specific SSC but also enables the relative comparison across cities within the same country or across countries.

This paper achieves its objectives through analyzing thoroughly the related literature review, identifying the deficiencies of each of the reported models and proposing a new model that addresses these issues. The paper devises a conceptual model which will be developed and tested in a follow up research.

\section{SMART CITIES, SMART SUSTAINABLE CITIES AND RELATED CONCEPTS}

The SC and SSC are being used interchangeably in the literature. To understand the linkages between the two concepts, we will review what "sustainable", "smart" and "cities" are and then discuss these two concepts.

\section{1. "Sustainable" Concept}

The word "sustainable" is a normative and socially constructed concept that is used to indicate development level. This means that the definition of sustainable development or sustainability in a broader sense cannot be based on an inductive approach. The concept has to be defined based on a deductive approach. For this reason, we use the classic definition of sustainable development developed by Brundtland (WCED, 1987) as an out basis towards identifying the limits of the SSC concept. Brundtland states that "Sustainable development is development that meets the needs of the present without compromising the ability of future generations to meet their own needs". Two main concepts are highlighted in this definition namely that of "needs" especially those of the poor and the environment's capacity to meet present and future needs. This definition is global in nature. To use it at the country level, an amendment is needed. For example, the Swedish government has solved this by defining a socalled "generational goal" stating that "the overall goal of Swedish environmental policy is to hand over to the next generation a society in which the major environmental problems in Sweden have been solved, without increasing environmental and health problems outside Sweden's borders" (Gabrys, 2014). Such an addition can be useful for countries and their constituents such as cities and connotes the context of the city.

\section{2. "Smart" Concept}

The word "smart" is controversial. Some researchers consider it referring to an instrumental rather than a normative concept. From an instrumental perspective, smart 
connotes category of products, services and systems in which ICT plays a major role. This interpretation is not agreed upon in the literature. For some researchers in the field, the word "smart" is regarded as a desired outcome rather than an instrumental concept, which makes it a normative concept as is the case with the concept of sustainability (Allwinkle, 2011).Tracing the roots of the word smart in the context of cities can contribute to an understanding of how the term smart is being loaded. In marketing language, smartness is centered on a user perspective (Klein, 2008). In the urban planning field, the smartness in smart growth is treated as a normative claim and ideological dimension. Being smarter entails strategic directions. Governments and public agencies at all levels are embracing the notion of smartness to distinguish their new policies, strategies, and programs for targeting sustainable development, sound economic growth, and better quality of life for their citizens (Centre on Governance, 2003).

The smartness in smart technologies also merits attention. Technologies had saturated into the commercial application of intelligent-acting products and services, artificial intelligence, and thinking machines (Moser, 2001). Smartness in the technology context implies the automatic computing principle like self-configuration, self-healing, self-protection, and self-optimization (Spangler et. al, 2010). Smart homes, smart buildings, and larger smart constructions like airports, hospitals or university campuses are equipped with a multitude of mobile terminals and embedded devices as well as connected sensors and actuators (Klein and Kaefer, 2008). A smart ecosystem is a conceptual extension of smart space from the personal context to the larger community and the entire city (Yovanof and Hazapis, 2009).

\section{3. "Cities" Concept}

A "City" is a place where people live that is larger or more important than a town. It is an area where many people live and work (Webster, 2015). In this research, cities constitute the object to which both smart and sustainable are linked. It is used to indicate the types of human structures and environments where smart solutions for sustainable development may exist. Unlike the case of "Smart", the concept of cities cannot be seen as instrumental mainly because the existence of cities is taken for granted. Instead of researching the adequacy of cities for sustainable development, the focus is on what could be made to make cities more sustainable.

Cities are considered key elements for the future as they play a prime role in social and economic aspects worldwide, and have an enormous impact on the environment (Mori and Christodoulou, 2012). Currently most the World resources are consumed in cities, contributing to their economic importance on one hand and to their poor environmental performance on the other hand. Promoting sustainability has been, in many cases, interpreted through the promotion of natural capital stocks. Other, more recent interpretations of urban sustainability have promoted a more anthropocentric approach, which regards the human being as the central fact of the universe and according to which cities should respond to people's needs through sustainable solutions for social and economic aspects (Turcu, 2013).

Blending these three different terms lead to the introduction of various definitions for the concept at hand by the international community, governments, Academia and private sector. Currently, there exists an abundant literature on smart cities' definitions. In some instances, the sustainability component is explicitly mentioned in the definition while not in others. To ensure that the sustainability aspect in smart cities is not overlooked, the ITU Telecommunication Focus Group on Smart 
Sustainable Cities (ITU-T FGSSC) conceptualized the new term "Smart Sustainable Cities". The latter could be taken as a variant of smart cities including some of the core features of eco-cities/sustainable cities.

\section{SSCS DEFINITION}

(Giffinger at al., 2007) consider smart as performing in a forward-looking way and focuses on issues such as awareness, flexibility, transformability, synergy, individuality, self-decisiveness, and strategic behavior. In addition, some definitions (e.g. Harrison et al's study) note that a smart city is an instrumented, interconnected, and intelligent city. In contrast, the Natural Resources Defense Council defines smarter in the urban context as more efficient, sustainable, equitable, and livable. (Toppeta, 2010) emphasizes the improvement in sustainability and livability. (Washburn et. al, 2010) views a smart city as a collection of smart computing technologies applied to critical infrastructure components and a service noting that smart computing refers to a new generation of integrated hardware, software, and network technologies that provide IT systems and real-time awareness of the real World and advanced analytics and actions that optimize business processes.

One reason that could stand behind the unavailability of a standardized definition is that the term has been applied to two different types of "domains." On one hand, it has been applied to "hard" domains where technologies can play a crucial role in the functions of the systems. These domains include but are not limited to buildings, energy grids, natural resources and mobility (Neirotti et al, 2014). On the other hand, the term has also been applied to "soft domains" such as, education, culture, policy innovations, social inclusion, and government, where the application of ICT is not usually critical. Another reason for the chaos related to this phenomenon is the existence of terms that are similar to "smart cities" namely digital, intelligent, virtual, ubiquitous, information, learning and knowledge city. These terms refer to more specific and less inclusive levels of a city, so that the concepts of smart cities often include them (Caragliu et al., 2011; Deakin and Al Waer, 2011; Townsend, 2013).

In an attempt to standardize the definition of SSC while taking the above discussants' opinions into consideration, the ITU performed an in-depth analysis to determine what would be a comprehensive and inclusive definition of a smart sustainable city from the perspective of the work being undertaken by the Focus Group on Smart Sustainable Cities (FG-SSC). Around 120 of definitions were analyzed to identify what makes a smart sustainable city. Based on the conducted analysis, a comprehensive definition was presented on the basis of the below mentioned specifications for a SSC (ITU, 2014):

- Improve the quality of life of its citizens.

- Ensure tangible economic growth such as higher standards of living and employment opportunities for its citizens.

- Improve the well-being of its citizens including medical care, welfare, physical safety and education.

- Establish an environmentally responsible and sustainable approach which "meets the needs of today without sacrificing the needs of future generations". 
- Streamline the physical infrastructure based services such as transportation (mobility), water, utilities (energy), telecommunications, and manufacturing sectors.

- Reinforce prevention and handling functionality for natural and man-made disasters including the ability to address the impacts of climate change.

- Provide an effective and well-balanced regulatory, compliance and governance mechanisms with appropriate and equitable policies and processes in a standardized manner.

The SSC comprehensive definition reads as follows "A smart sustainable city is an innovative city that uses information and communication technologies (ICTs) and other means to improve quality of life, efficiency of urban operation and services, and competitiveness, while ensuring that it meets the needs of present and future generations with respect to economic, social and environmental aspects". It is likely to become the United Nations standard definition of Smart Sustainable Cities given its acceptance by Academia, industry and international community. It is a comprehensive definition that provides a standardized basis for building performance measurement models. We will use it in this paper given its comprehensiveness and adoption at the global level.

\section{SSCS DIMENSIONS}

The dimensions of SSC vary across the literature as it is not relevant for all actors and perspectives in the same manner. For instance, from the angle of sustainability, researchers argue that whether or not smart technologies are used is not of importance as long as the solutions adopted lead to additional sustainability. From this perspective, the concept of a sustainable city would be enough. On another hand, from an ICT industry perspective, researchers and practitioners argue that the industry works with smart solutions irrespective of their impact on sustainability as the latter is not within their priorities. Thus, the concept of the smart city is considered appropriate and sufficient for them. These different opinions are valid as they connote the country's objectives and focus in relation to SSCs. In other words, the city's context impacts its implementation for SSCs. Because of the validity of this variance between contexts of cities, identifying the dimensions of SSC is needed. A thorough literature review on the dimensions of SCs and SSCs indicates a differences and commonalities that are worth noting.

(Giffinger et al, 2007) identified four components of a smart city namely: industry, education, participation, and technical infrastructure. This list of four components has since been expanded by the Centre of Regional Science at the Vienna University of Technology which has identified six main components (Giffinger and Gudrun, 2010). These components are as follows: Smart economy, Smart mobility, Smart environment, Smart people, Smart living and Smart governance. These components relied on the theories of urban growth and development namely: regional competitiveness, transport and ICT economics, natural resources, human and social capital, quality of life, and participation of society members. The main addition to the previous list that should be highlighted is the inclusion of the "quality of life." This component emphasizes the definition of a smart sustainable city as a city that increases the life quality of its citizens (Giffinger et al., 2007) (ITU-T, 2014). However, many researchers argue that a separate dimension should not be attributed to the quality of life since all the actions taken in the remaining areas identified should aim at enhancing the 
quality of life of citizens but could be considered as a basic component.

Researchers take different stands when identifying the components of a SSC. (Dirks and Keeling, 2009) stress the importance of the organic integration of a city's various systems in creating a smart city. The systems of cities include but are not limited to transportation, energy, education, health care, buildings, physical infrastructure, food, water and security. Researchers who advocate for this integrated view of a city often highlight the fact that cities are characterized by a dense environment in which no system operates in seclusion. (Kanter and Litow, 2009) reiterate this view and affirm that introducing intelligence in each subsystem of a city on one-to-one basis is insufficient to create a smart city, as cities should be dealt with holistically. However, many other researchers, with the intent of clarifying a concept have separated it into many features and dimensions.

(Lombardi et al., 2012) associated the six components presented in (Giffinger et al, 2007) with different aspects of urban life. The smart economy has been associated with the presence of industries in the field of ICT or employing ICT in production processes. Smart education focused on building the ICT capacities of citizens; smart governance has been linked to the use of ICT to achieve democracy and transparency; Smart mobility refers to the use of ICT in modern transport technologies to improve urban traffic; Smart environment has been linked to harnessing ICT efficiently for achieving sustainability; and Smart living refers to the use of ICT for achieving a secured and enhanced quality of life for citizens. According to (Nam and Pardo, 2011), the key components of a smart city are the technology, the people (creativity, diversity, and education), and the institutions (governance and policy). A city is really smart when investments in human and social capital, together with ICT infrastructures, boost sustainable growth and enhance the quality of life. Many other authors discussed the key dimensions of smart and sustainable cities. Table 1 provides a summary of the main dimensions discussed in the literature.

The ITU, through its FGSSC, conceptualized the notion of SSC and focused on the fact that it entails more than just the implementation of technologies and strategies aimed at meeting today's needs without compromising those of future generations. It is also about understanding the city itself: its identity and its goals, its stakeholders and their priorities, thus identifying the attributes that would tailor to the uniqueness of each city while enhancing its overall living quality and sustainability with the support of ICTs. The FGSSC identified six dimensions along with attributes. The six dimensions are: Economy, Mobility, Environment, Society, Quality of life and Governance.

By carefully analyzing the SSC dimensions devised by the ITU-T FGSSC, we note that a direct mapping between them is possible. The ITU-T FGSSC did not use the word "smart" in the name of the dimensions. It used the word "Society" instead of "People" and explicitly referred to "Quality of Life" instead of "Living". As mentioned earlier, selected authors argue that Quality of Life should not be a dimension on its own believing that it is a crosscutting concern. In both cases, when assessing the performance of a SSC, quality of life of citizens should be at the core. 
Table 1: Key Dimensions of a Smart (Sustainable) City

\begin{tabular}{|c|c|}
\hline Key dimensions of a smart city & Source \\
\hline $\begin{array}{l}\text { Economic (GDP, sector strength, international } \\
\text { transactions, foreign investment) } \\
\text { Human (talent, innovation, creativity, education) } \\
\text { Social (traditions, habits, religions, families) } \\
\text { Environmental (energy policies, waste and water } \\
\text { management, landscape) } \\
\text { Institutional (civic engagement, administrative authority, } \\
\text { elections) }\end{array}$ & (Barrionuevo et al., 2012) \\
\hline $\begin{array}{l}\text { Management and organizations } \\
\text { Technology } \\
\text { Governance } \\
\text { Policy context } \\
\text { People and communities } \\
\text { Economy } \\
\text { Built infrastructure } \\
\text { Natural environment }\end{array}$ & (AlAwadhi et al., 2102) \\
\hline $\begin{array}{l}\text { Technology } \\
\text { Economic development } \\
\text { Job growth } \\
\text { Increased quality of life } \\
\end{array}$ & (Eger , 2009) \\
\hline $\begin{array}{l}\text { Economy } \\
\text { Mobility } \\
\text { Environment } \\
\text { People } \\
\text { Governance }\end{array}$ & (Giffinger et al., 2007) \\
\hline $\begin{array}{l}\text { Human capital (e.g. skilled labor force) } \\
\text { Infrastructural capital (e.g. high-tech communication } \\
\text { facilities) social capital (e.g. intense and open network } \\
\text { linkages) } \\
\text { Entrepreneurial capital (e.g. creative and risk-taking } \\
\text { business activities) }\end{array}$ & $\begin{array}{l}\text { (Kourtit and Nijkamp, } \\
\text { 2012) }\end{array}$ \\
\hline $\begin{array}{l}\text { IT education } \\
\text { IT infrastructure } \\
\text { IT economy } \\
\text { Quality of life }\end{array}$ & (Mahizhnan, 1999) \\
\hline $\begin{array}{l}\text { Economic socio-political issues of the city } \\
\text { Economic-technical-social issues of the environment } \\
\text { Interconnection } \\
\text { Instrumentation } \\
\text { Integration } \\
\text { Applications } \\
\text { Innovations }\end{array}$ & (Nam and Pardo, 2011) \\
\hline
\end{tabular}


Quality of life

Sustainable economic development

Management of natural resources through participatory

policies

Convergence of economic,

Social, and environmental goals
(Thuzar, 2011)

As for the role of ICTs in SSCs, the ITU-T FGSS highlights their crucial existence due to their ability to act as a digital platform from which an information and knowledge network can be created. Such a network then allows for the aggregation of information and data not only for the purpose of data analysis, but also towards an improved understanding on how the city is functioning in terms of resource consumption, services, and lifestyles. Information made available by these digital platforms would serve as a reference for stakeholders to take action and create policy directions that would eventually improve the quality of life for the citizens and the society as a whole. (Nam and Pardo, 2011) refer to technology as a crucial dimension of a smart city. This viewpoint is supported by many authors and practitioners in the field. However, another group of researchers including the ITU_T FGSSC attribute a high importance to the role of ICT in the establishment of SSC but do not consider technology as a dimension of the city but rather look at it as the component that is at the core of SSC and that acts as the nerve centre orchestrating all the interactions between the different pillars and the infrastructure. It is an indispensable ingredient of the SSC that acts as a glue to connect different everyday living services to public infrastructures. It is the orchestrator of the various elements of the SSC which should coexist (IEEE SC, 2014).

\section{LITERATURE REVIEW}

Literature shows a variance in the dimensions also referred to as pillars, axes or sectors of a SSC. An extensive analysis of these dimensions was recently conducted by the focus group on SSCs of the ITU. The analysis led to setting the dimensions to six, namely: smart economy, smart people, smart governance, smart mobility, smart living and smart environment (ITU-T FG-SSC, 2014).

Given the fact that a SSC necessitates the coexistence of numerous dimensions, assessing the performance of SSC necessitates assessing the performance at the different dimensions level, thus a multidimensional model is needed. Research indicates the existence of many measurement models targeting cities which could be used to measure smartness. However, they focus, in varied degrees, on a subset of the dimensions of the SSC and they are not sensitive to the context of cities.

In what follows, we will explore the main related measurement models adopted internationally. An overview of each selected model will be given along with a synopsis of its purpose. The models include, but are not limited to: Global Competitiveness Index; Network Readiness Index; ICT Development Index; Global Innovation Index; Egovernment Development Index; Digital Economy Ranking; Change Readiness Index; Green City Index, and Better Life Index. A discussion will follow the overview of the models to highlight their deficiencies in relation to measuring performance of SSC and results of the research. 


\subsection{Global Competitiveness Index (GCI)}

The GCI, managed by the World Economic Forum (WEF) since 2005, aims at monitoring the microeconomic and macroeconomic foundations of national competitiveness. It provides a holistic tool to encourage the dialogue among stakeholders about the needed strategies and policies to assist countries in overcoming the obstacles to improve competitiveness. This work focuses on the criticality of structural economic fundamentals for sustainable development (WEF, 2014). The concept of competitiveness involves static and dynamic components grouped into twelve pillars of competitiveness namely: Institutions; Infrastructure; Macroeconomic environment; Health and primary education; Higher education and training; Goods market efficiency; Labor market efficiency; Financial market development; Technological Readiness; Market size; Business sophistication; and Innovation. GCI captures through its components a subset of the dimensions of a SSC namely Economy through the focus on competitiveness, finance, innovation and labor; and Quality of life through education and health.

\subsection{Network Readiness Index (NRI)}

The NRI, managed by the WEF for more than thirteen years, provides policymakers, business leaders, and concerned citizens with important observations in relation to the current market conditions and connectivity status across the globe. It assists in identifying the areas where technology could be used to accelerate its positive impact on citizens. It is an important model as it focuses on the increasing crucial role of ICT diffusion in the process of economic growth and provides an assessment tool for a systematic comparison of the ICT development of countries around the globe (WEF, 2014). The model is comprised of four sub indices. These measure the environment for ICTs; the readiness of a society to use ICTs; the actual usage of all main stakeholders; and, finally, the impacts that ICTs have on the economy and in society. NRI focuses on ICT as the centre of everything. Although ICT is the orchestrator in the case of SSC; however it is not considered as a dimension on its own.

\subsection{ICT Development Index (IDI)}

The IDI, managed by the ITU since 2008, aims at measuring the level and evolution over time of ICT developments in countries and relative to other countries. It also monitors the progress in ICT development in both developed and developing countries and the progress in relation to bridging the digital divide. Analyzing the model indicates that the transformation towards the information society goes through three different stages. Stage 1 or "ICT readiness" reflects the level of networked infrastructure and access to ICTs. Stage 2 or "ICT intensity" reflects the level of use of ICTs in the society. Stage 3 or "ICT impact" reflects the outcome of efficient and effective ICT use. Advancing through these stages depends on a combination of three factors: the availability of ICT infrastructure and access, a high level of ICT usage and the capability to use ICTs effectively (ITU, 2014). The model measures also the development potential of ICTs based on available capabilities and skills. It is a composite index combining eleven indicators into one benchmark measure. As is the case with NRI, the focus of the model is on ICT. It measures not only the advancement in ICT but also its impact on citizens. This is needed in assessing SSC as ICT impact the quality of life of citizens but it is not enough given the multidimensionality of the concept. 


\subsection{Global Innovation Index (GII)}

The GII, managed by the World Intellectual Property Organization (WIPO), Cornell University and INSEAD, the business school for the world over the last 7 years, has established itself as a leading reference on innovation. It aims at providing a unique tool for refining innovation policies, creating an accurate picture on the role of science, technology and innovation in sustainable development, and assessing where more efforts are urgently needed in the area. The GII relies on two sub-indices namely the Innovation Input Sub-Index and the Innovation Output Sub-Index. Each sub index is built around pillars. Each pillar composing the model is divided into three sub-pillars and each sub-pillar is composed of individual indicators, for a total of eighty one indicators. The GII focuses on crucial areas of SSC especially innovation which is linked to entrepreneurship and economy. As is the case with the remaining indices, the GII focuses on main areas of importance to SSC, that is innovation which is linked to entrepreneurship and economy but this is not enough and measuring performance of $\mathrm{SSC}$ requires more dimensions to be assessed.

\subsection{E-government Development Index (EGDI)}

The EGDI, managed by the Division for Public Administration and Development Management (DPADM) at the United Nations Department of Economic and Social Affairs (UNDESA) since 2002, is used to measuring the willingness and capacity of national administrations to use ICTs to deliver public services (UNDESA, 2014). This measure of the index is useful for government officials, policy makers, researchers and representatives of civil society and the private sector to establish a thorough understanding of the comparative assessment of the relative position of a country in utilizing e-government for the delivery of citizen-centric services (Savodelli et al., 2013). The model is composed of the Online Service Index (OSI), Telecommunication Infrastructure Index (TII) and the Human Capital Index (HCI). It is based on an expert assessment survey of the online presence of states of the United Nations, which assesses national websites and how e-government policies and strategies are applied in general and in specific sectors for delivery of essential services. The EGDI captures advancement in terms of e-government services which is mainly linked to the important governance dimension of SSC. Covering one or a subset of dimensions of SSC is not enough to comprehensively assess SSC performance.

\subsection{Green City Index}

The Green City Index, managed by Economist Intelligence Unit (EIU) and sponsored by Siemens since 2009, aims at comparing major cities in terms of their environmental performance and policies and assisting in understanding the strengths and weaknesses of each city and their performance against peers. It covers $\mathrm{CO}_{2}$ emissions, energy, buildings, land use, transport, water and sanitation, waste management, air quality and environmental governance (KPMG, 2009). The index is composed of thirty quantitative and qualitative indicators distributed along eight to nine categories depending on the region. Measuring quantitative and qualitative indicators together means the indices are based on current environmental performance as well as the city's intentions to become greener. This index focuses on the environment dimension of SSC which is one dimension of a set of 6 dimensions as identified by the ITU. 


\subsection{Digital Economy Ranking}

Digital Economy Ranking, previously named E-Readiness ranking and managed by the EIU since 2000, is used to assess the world's largest economies on their ability to absorb ICT and use it for economic and social benefit. It assesses the quality of a country's ICT infrastructure and the ability of its consumers, businesses and governments to use ICT to their benefit (EIU, 2010). The digital economy rankings model consists of over hundred of separate quantitative and qualitative criteria organized into six primary categories namely: connectivity and technology infrastructure; Business environment; Social and cultural environment; Legal environment; Government policy and vision; and Consumer and business adoption. This index touches, unlike others, different aspects of SSC. It covers technology which is the nerve connecting services in an SSC and touches the economy, society, governance and culture. However, it does not consider the elements relating to environment and sustainability which are crucial in assessing performance of SSC.

\subsection{Change Readiness Index (CRI)}

The Change Readiness Index, managed by KPGM International Cooperative and Oxford Economics since 2010, is designed to define and assess those characteristics that based on our knowledge of economic and growth theory and past evidence are likely to determine a country's readiness for change. Rather than focus on a country's performance to date as most indices do, the CRI takes a forward-looking perspective by capturing the underlying factors that are likely to determine a country's capability for managing change hypothesized to support sustained growth in the long-term. The Index captures not only government capability but the potential of the country as a whole, including the private sector and civil society, to cope with and respond effectively to change (KPMG, 2012). Many of the indicators focus on policies and capacities that should facilitate healthy, dynamic, and responsive markets. The conceptual model of the index indicates that indicators belonging to social, governance and economic capabilities, all together highlight readiness for change. This index captures readiness for change. Although this is not a dimension in SSC, but it keeps an eye on readiness towards the transformation to SSC is of upmost importance.

\subsection{Better Life Index}

The Better Life Index (BLI), managed by the Organization for Economic Cooperation and Development (OECD) since 2011, focuses on people's well-being and societal progress. The index does not only consider the functioning of the economic system but also the diverse experiences and living conditions of people and households (OECD, 2015).The index, which required more than a decade of work to be introduced, identified eleven dimensions as being essential to well-being, from health and education to local environment, personal security and overall satisfaction with life, as well as more traditional measures such as income. The dimensions include housing, income, jobs, community, education, environment, governance, health, life satisfaction, safety and work- life balance. This index is directly related to assessing the quality of life which lies at the core of the SSC objectives. It touches on various dimensions of SSC including society, economy, environment and governance. However, it does not relate to the mobility dimension. Table 2 summarizes these models and sheds light on the main objectives of each of the reported models. 
Table 2: Selected measurement models for aspects of SSC

\begin{tabular}{|c|c|c|c|}
\hline Model & Managing Entity & $\begin{array}{l}\text { Base } \\
\text { Year }\end{array}$ & Objective \\
\hline $\begin{array}{l}\text { Digital } \\
\text { Economy } \\
\text { Ranking }\end{array}$ & $\begin{array}{l}\text { Economist } \\
\text { Intelligence Unit }\end{array}$ & 2000 & $\begin{array}{l}\text { Assesses the quality of a country's ICT } \\
\text { infrastructure and the ability of its } \\
\text { consumers, businesses and governments } \\
\text { to use ICT to their benefit. }\end{array}$ \\
\hline $\begin{array}{l}\text { Network } \\
\text { Readiness } \\
\text { Index }\end{array}$ & $\begin{array}{l}\text { World Economic } \\
\text { Forum }\end{array}$ & 2000 & $\begin{array}{l}\text { Provides policymakers, business leaders, } \\
\text { and concerned citizens with important } \\
\text { observations in relation to the current } \\
\text { market conditions and connectivity status } \\
\text { across the globe. }\end{array}$ \\
\hline $\begin{array}{l}\text { E-government } \\
\text { Development } \\
\text { Index }\end{array}$ & $\begin{array}{l}\text { United Nations } \\
\text { Department of } \\
\text { Economic and } \\
\text { Social Affairs }\end{array}$ & 2002 & $\begin{array}{l}\text { Measures the willingness and capacity of } \\
\text { national administrations to use ICTs to } \\
\text { deliver public services. }\end{array}$ \\
\hline $\begin{array}{l}\text { Global } \\
\text { Competitiveness } \\
\text { Index }\end{array}$ & $\begin{array}{l}\text { World Economic } \\
\text { Forum }\end{array}$ & 2005 & $\begin{array}{l}\text { Focuses on the criticality of structural } \\
\text { economic fundamentals for sustainable } \\
\text { development. }\end{array}$ \\
\hline $\begin{array}{l}\text { Global } \\
\text { Innovation } \\
\text { Index }\end{array}$ & $\begin{array}{l}\text { World Intellectual } \\
\text { Property } \\
\text { Organization } \\
\text { (WIPO), Cornell } \\
\text { University and } \\
\text { INSEAD }\end{array}$ & 2007 & $\begin{array}{l}\text { Provides a unique tool for refining } \\
\text { innovation policies, creating an accurate } \\
\text { picture on the role of science, technology } \\
\text { and innovation in sustainable } \\
\text { development, and assessing where more } \\
\text { efforts are urgently needed in the area. }\end{array}$ \\
\hline $\begin{array}{l}\text { ICT } \\
\text { Development } \\
\text { Index }\end{array}$ & $\begin{array}{l}\text { International } \\
\text { Telecommunicatio } \\
\text { n Union }\end{array}$ & 2008 & $\begin{array}{l}\text { Monitors the progress in ICT } \\
\text { development in both developed and } \\
\text { developing countries and the progress in } \\
\text { relation to bridging the digital divide. }\end{array}$ \\
\hline $\begin{array}{l}\text { Green City } \\
\text { Index }\end{array}$ & $\begin{array}{l}\text { Economist } \\
\text { Intelligence Unit }\end{array}$ & 2009 & $\begin{array}{l}\text { Compares major cities in terms of their } \\
\text { environmental performance and policies } \\
\text { and assists in understanding the strengths } \\
\text { and weaknesses of each city and their } \\
\text { performance against peers }\end{array}$ \\
\hline $\begin{array}{l}\text { Better Life } \\
\text { Index }\end{array}$ & $\begin{array}{l}\text { Organization for } \\
\text { Economic Co- } \\
\text { operation and } \\
\text { Development }\end{array}$ & 2010 & $\begin{array}{l}\text { Monitors people's well-being and } \\
\text { societal progress }\end{array}$ \\
\hline $\begin{array}{l}\text { Change } \\
\text { Readiness } \\
\text { Index }\end{array}$ & $\begin{array}{l}\text { KPGM } \\
\text { International } \\
\text { Cooperative and } \\
\text { Oxford Economics }\end{array}$ & 2010 & $\begin{array}{l}\text { Shows the country's capability for } \\
\text { managing change hypothesized to } \\
\text { support sustained growth in the long- } \\
\text { term. Change readiness is measured } \\
\text { against three different categories namely: } \\
\text { Social capabilities; Governance } \\
\text { capabilities and Economic capabilities. }\end{array}$ \\
\hline
\end{tabular}




\section{DISCUSSION AND RESULTS}

The models overviewed in the previous section were selected out of a much more extensive list available in the literature due to their relevance to the topic and their coverage to aspects of the SSCs. Table 1 summarized the listed models and shows that the models focus, in varied degrees, on facets related to the social and economic development of a country, its infrastructure and its environmental policies. In specific, they considered the national economic competitiveness status and the infrastructure in terms of network readiness and ICT developments. A number of models focused on the ability to absorb ICT and use it for economic and social benefit in addition to the capacity of national administrations to use ICTs to deliver public e-government services. Given that the ultimate objective of a SSC is to achieve a high quality of life for its citizens, ICT is an enabler for SSCs and e-government implementation is a prerequisite for the transformation towards SSCs; these models could be used to partially assess the performance of SSCs according to the selected dimensions. Another set of models focused on the country's capability for managing change and its environmental performance and policies. These elements are crucial to grant sustainability, thus they also cover partial dimensions of a SSC. Therefore, no single comprehensive model assessing the performance of SSC at all dimensions is available in the literature and this is a gap in knowledge. Also, there exists a theoretical debate as to what smartness means to different cities in different contexts. None of the reported models captured the context of the country being assessed to observe its impact on the output measure.

While exploring the models, it was clear that the model at hand either covers one or a subset of the dimensions used as guidelines for assessing performance of SSC but none covered all dimensions of SSC. To bridge this gap, we propose a conceptual model for a new methodological model for measuring smartness of a SSC. The model operates in two phases. The first phase captures the smartness measure of a particular SSC through observing the performance of a city along the six dimensions adopted by the ITU as previously discussed. Each dimension is divided into core sub dimensions that are in turn concretely quantified through an identified set of indicators. One limitation is the identification of this core sub dimensions and set of indicators. Further research needs to be conducted to ensure proper selection and objectivity. The second phase of the model captures the context of the city being assessed in an attempt to allow proper comparability. For instance, using models or indices in many instances to measure performance of cities may be interesting but not always useful if contextual factors are not captured. One city may be focusing on a dimension more than others and this focus could vary. Any measure capturing the smartness of cities should take this context variance into consideration. Figure 1 presents the two phases of the proposed conceptual model for measuring smartness of SSC. 


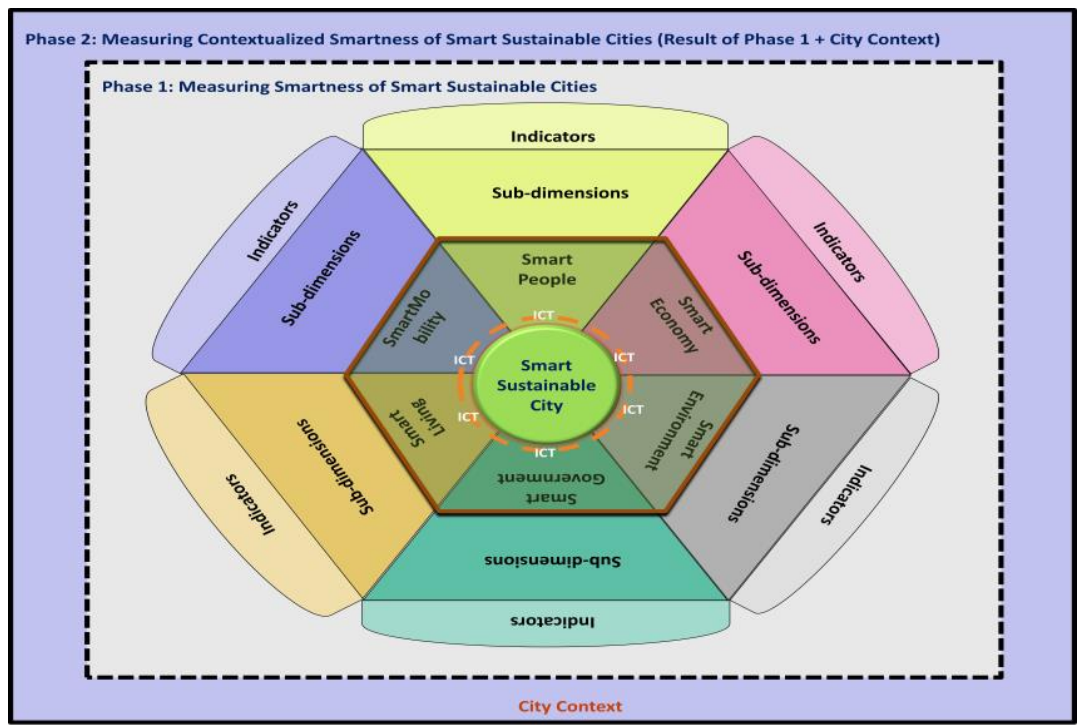

Figure 1: Phases of the proposed model for measuring SSC

The proposed multidimensional model assists in building an integrated vision of a city's smartness. It also provides guidelines for policy makers and stakeholders on the core dimensions and sub-dimensions to monitor in order to enhance the city's transformation towards being a SSC. The latter will be identified through future research and analysis.

\section{CONCLUSION}

There exists a theoretical debate as to what smartness means in different cities with different contexts and a gap in knowledge in relation to the holistic assessment of the smartness level of a SSC. No single comprehensive model tackling the dimensions of the SSC is available in the literature. To address this gap, a new multidimensional model is proposed capturing the smartness of a city while sensitizing it with its context peculiarities.

\section{REFERENCES}

Alawadhi, S., Aldama-Nalda, A., Chourabi, H., Gil-Garcia, J.R., Leung, S. , Mellouli, S., Nam, T., Pardo, T.A., Scholl, H.J., and Walker, S. "Building Understanding of Smart City Initiatives," Lecture Notes in Computer Science 7443 (2012) 40-53.

Allwinkle, S., Cruickshank, P.: Creating Smart-er Cities - An Overview. Journal of Urban Technology 18(2), 1-16 (2011)

Barrionuevo, J.M, Bemone, P, and Ricart, J.E.“SmartCities, Sustainable Progress," IESEInsight 14 (2012) 50-57

Caragliu, A., Chiara, B. \& Peter, N. (2011). Smart cities in Europe. Journal of urban technology, Vol. 18, pp. 65-82.

Chiara Del Bo, Peter Nijkamp. 2011. Smart cities in Europe. Amsterdam: VU University of Amsterdam.

Center on Governance (2003). Smart Capital Evaluation Guidelines Report:

Performance Measurement and Assessment of Smart Capital. Ottawa, Canada: 
University of Ottawa. Available at http://www.christopherwilson.ca/papers/Guidelines_report_Feb2003.pdf.

Cohen, B. "The Top 10 Smart Cities On The Planet." Fast Company, 11 Jan. 2011. Web. Last accessed 12 Feb. 2014. http://www.fastcoexist.com/1679127/the-top-10smart-cities-on-the-planet

Deakin,M., and AlWaer, H., "From Intelligent to Smart Cities" Intelligent Buildings International3:3 (2011)140-152.

Dirks, S., Gurdgiev, C. and Keeling, M. Smarter Cities for Smarter Growth: How Cities Can Optimize Their Systems for the Talent-Based Economy (Somers, NY: IBM Global Business Services, 2010).

Eger, J. M.,"SmartGrowth, SmartCities, and the Crisis at the Pump A Worldwide Phenomenon,"I-Ways 32: 1 (2009) 47 -53.

EIU (2010). Digital Economy Rankings, Beyond e-readiness. Economist Intelligence Unit (EIU), Economist Publications.

Forbes (2014). Smart Cities -- A \$1.5 Trillion Market Opportunity. Forbes LLC. Web. Accessed, Retrieved from:

http://www.forbes.com/sites/sarwantsingh/2014/06/19/smart-cities-a-1-5-trillionmarket-opportunity/

Gabrys, J.: Programming environments - environmentality and citizen sensing in the smart city. Environment and Planning D: Society and Space 32, 30-48 (2014)

Giffinger, R., Fertner, C., Kramar, H., Kalasek, R.,Pichler-Milanovis, N., \& Meijers, E. (2007). Smart Cities: Ranking of European Medium-Sized Cities. Vienna, Austria: Centre of Regional Science (SRF), Vienna University of Technology. Available at http://www.smart-cities.eu/download/smart_cities_final_report.pdf.

Giffinger, R., \& Gudrun, H. (2010). Smart cities ranking: An effective instrument for the positioning of cities? ACE: Architecture, City and Environment, 4(12), 7 -

25.Availableathttp://upcommons.upc.edu/revistes/bitstream/2099/8550/7/ACE_12_SA _10.pdf.

IEEE SC (2014). IEEE Smart Cities (SC). http://smartcities.ieee.org/. (Accessed on December 20 2014).

IEEE (2015) http://smartcities.ieee.org/news-bulletin/march-2015/editorial.html, accessed: Sunday, 16 August 2015 at 11:00 pm

International Telecommunication Union (ITU). http://www.itu.int/en/ITU-

D/Pages/default.aspx. (Accessed on January 04, 2015).

International Telecommunication Union (ITU). 2014. Measuring the Information Society Report. http://www.itu.int/en/ITU-

D/Statistics/Documents/publications/mis2014/MIS2014_without_Annex_4.pdf (Accessed on December 28 2014)

ITU-T FG-SSC (2014). Technical Report on Smart Sustainable Cities: An analysis of definitions.

United Nations, International Telecommunication Union (ITU-T), Focus Group on Smart Sustainable Cities (FG-SSC). 
Kanter R.M., and Litow, S.S., Informed and interconnected: A manifesto for smarter cities, Harvard Business School General Management Unit, 09-141, 2009.

Klein, C., \& Kaefer, G. (2008). From smart homes to smart cities: Opportunities and challenges from an industrial perspective. In Proceedings of the 8th International Conference, NEW2AN and 1st Russian Conference on SmartSpaces, ruSMART 2008 (St. Petersburg, Russia, Sep 3-5). Available at http://www.springerlink.com/content/d053p7u7g42u573p/.

KPMG (2012). 2012 Change Readiness Index. KPMG International Cooperative and Overseas Development Institute (ODI).

Kourtit, P. Nijkamp, and D. Arribas, "Smart Cities in Perspective - A Comparative European Study by Means of Self-organizing Maps" Innovation: The European Journal of Social Science Research25: 2 (2012) 229-246.

Lee, S.Y., Jin, K.Y. \& Choi, S.H. (2013). A Study on Convergence Technology for Building of Smart City. ICCA 2013, ASTL Vol. 24, pp. 113 - 116.

Lombardi,P.,Giordano, S.,Farouh,H.,andYousef W.,"Modelling the Smart City Performance,"Inno-vation: The European Journal of Social Science Research 25:2(2012)137-149.

Mahizhnan,A.,"SmartCities: The Singapore Case,’Cities 16:1(1999)13-18.

Mori K., \& Christodoulou A. (2012). "Review of Sustainability Indices and Indicators: Towards a New City Sustainability Index (CSI)," Environmental Impact Assessment Review 32: 1 (2012) 94-106.

Moser, M. A. (2001). What is smart about the smart communities movement? EJournal, 10/11(1). Available at http://www.ucalgary.ca/ejournal/

Mirriam Webster. http://www.merriam-webster.com/dictionary/city. (Accessed on May 01, 2015)

Nam, T., \& Pardo. T. (2011). Conceptualizing Smart City with Dimensions of Technology, People, and Institutions. Proceedings of the 12th Annual International Digital Government Research Conference, pp. 282-291.

Neirotti, P., De Marco, A., Cagliano, A. C., Mangano, G. \& Scorrano, F. (2014). Current trends in Smart City initiatives - Some stylised facts. Cities 38, 25-36.

OECD Better Life Index. http://www.oecdbetterlifeindex.org/. (Accessed on January 02 2015)

Savodelli. A., Misuraca. G. \& Codagone. C. (2013). Measuring the Public Value of eGovernment: The eGEP2.0 model. Electronic Journal of e-Government, Vol. 11, pp. 373- 388.

Spangler, W. S., Kreulen, J. T., Chen, Y., Proctor, L., Alba, A., Lelescu, A., \& Behal, A. (2010). A smarter process for sensing the information space. IBM Journal of Research and Development, 54(4). DOI: 10.1147/JRD.2010.2050541.

The Global Open Initiative. http://globalopendatainitiative.org/

Thuzar,M.,"Urbanization in South East Asia: Developing Smart Cities for the Future?," Regional Outlook (2011)96-100.

Townsend, A. (2013). Smart Cities - Big Data, Civic Hackers and the Quest for a new Utopia. Norton \& Company, USA: New York. 
Turcu,C. "Re-thinking Sustainability Indicators: Local Perspectives of Urban Sustainability,” Journal of Environmental Planning and Management 56: 5 (2013) 695-719.

UN-Habitat (2013). State of the World's Cities 2012/2013, Prosperity of Cities. UNHabitat for a better Urban Future, UN-Habitat Publications (HS/080/12E)

UNDESA (2014). United Nations E-Government Survey. United Nations Department of Economic and Social Affairs (UNDESA).

UNDESA (2012). World Urbanization Prospects, the 2011 Revision: Highlights. United Nations Department of Economic and Social Affairs (UNDESA), United Nations Populations (ST/ESA/SER.A/317)

WEF (2014). The Global Competitiveness Report 2014 - 2015. World Economic Forum (WEF). http://reports.weforum.org/global-competitiveness-report-20142015/methodology/\#read. (Accessed on January 05, 2015).

WEF (2014). The Global Information Technology Report, Rewards and Risks of Big Data. World Economic Forum (WEF) and INSEAD, Geneva, ISBN-13: 978-92-9504463-0.

WIPO (2014). The Global Innovation Index, the Human Factor in Innovation. World Intellectual Property Organization (WIPO), Geneva, ISSN 2263-3693.

World Commission on Environment and Development (WCED): Our common future. Oxford Univ. Press, Oxford (1987)

Yovanof, G. S., \& Hazapis, G. N. (2009). An architectural framework and enabling wireless technologies for digital cities \& intelligent urban environments. Wireless Personal Communications, 49(3), 445-463. Available at: http://www.springerlink.com/content/g1v63025217mt8x0/. 